\title{
ОСОБЛИВОСТІ УПРАВЛІННЯ МАРКЕТИНГОВОЮ ДІЯЛЬНІСТЮ ПІДПРИЄМСТВА В УМОВАХ ПАНДЕМІЇ
}

\section{FEATURES OF MANAGEMENT OF MARKETING ACTIVITIES OF THE ENTERPRISE IN THE CONDITIONS OF THE PANDEMIC}

\author{
Касич Алла Олександрівна \\ доктор економічних наук, профресор, \\ Київський національний університет технологій та дизайну \\ ORCID: https://orcid.org/0000-0001-7019-1541 \\ Малюшенко Олександра Олександрівна \\ студентка, \\ Київський національний університет технологій та дизайну \\ ORCID: https://orcid.org/0000-0002-3001-9621
}

Kasych Alla, Maliushenko Oleksandra

Kyiv National University of Technology and Design

\begin{abstract}
У статті було досліджено теоретичні аспекти управління маркетинговою діяльністю підприємства за сучасних умов господарювання та під впливом пандемії COVID-19. На основі дослідження поняття «управління маркетинговою діяльністю» було виокремлено ключові підходи та акценти до його забезпечення. У статті досліджено модель управління маркетинговою діяльністю підприємства з урахування потреб сучасного ринку та цілей досягнення ефективності маркетингу та діяльності підприємства в цілому. Маркетинг розглядається як важлива складова діяльності підприємства, а тому в процесі управління важливо розуміти функціональні завдання підсистеми управління маркетинговою діяльністю, принципи здійснення управління маркетингом. Ключовим чинником, який впливає не лише на маркетингові концепції, а й на моделі розвитку бізнесу в цілому $€$ пандемії COVID-19. У процесі управління маркетингом слід враховувати динамічну зміну поведінки споживачів. В статті визначено ключові тенденції у розвитку концепції маркетингу під впливом пандемії, серед яким автори зазначили: відбулось обмеження горизонту довгострокового бачення поведінки споживачів та переорієнтація на он-лайн заходи; зміна стилю спілкування між виробником та споживачем; нестабільність цін на ринках більшості найменувань продукції виробників; зміна логістичних ланцюгів постачання, як на стадії закупівель, так і на стадії постачання. Підприємства потребують поєднання: довгострокових та короткострових планів маркетингових заходів; розширення спектру методів дослідження ринка та заходів маркетингової діяльності; врахування результатів маркетингової діяльності в процесі удосконалення бізнес-моделей розвитку підприємств. Також в статті визначено особливості сучасного етапу розвитку маркетингу, під впливом яких відбувається фрактично зміна моделі маркетингової системи. На основі узагальнення дії чинників розвитку маркетингу, а також основних тенденцій авторами ідентиоріковано основні моделі маркетингу, серед яких цифровий, ситуативний та індивідуально-орієнтований маркетинг.
\end{abstract}

Ключові слова: маркетинг, маркетингова діяльність, складові маркетингової діяльності, управління маркетингом, цифровий маркетинг, ситуативний маркетинг, індивідуально-орієнтований маркетинг.

В статье были исследованы теоретические аспекты управления маркетинговой деятельностью предприятия в современных условиях хозяйствования и под влиянием пандемии COVID-19. На основе исследования понятия «управление маркетинговой деятельностью» были выделены ключевые подходы и акценты на его обеспечение. В статье исследована модель управления маркетинговой деятельностью предприятия с учетом потребностей современного рынка и целей достижения эффеективности маркетинга и деятельности предприятия в целом. Маркетинг рассматривается как важная составляющая деятельности предприятия, поэтому в процессе управления важно понимать фрункциональные задачи подсистемы управления маркетинговой деятельностью, принципы осуществления управления маркетингом. Ключевым фактором, который влияет не только на маркетинговые концепции, но и на модели развития бизнеса в целом пандемии COVID-19. B процессе управления маркетингом следует учитывать динамическое изменение поведения потребителей. 
В статье определены ключевые тенденции развития концепции маркетинга под влиянием пандемии, среди которых авторы отметили: произошло ограничение горизонта долгосрочного видения поведения потребителей и переориентация на он-лайн мероприятия; изменение стиля общения между изготовителем и потребителем; нестабильность цен на рынках большинства наименований продукции изготовителей; изменение логистических цепей снабжения, как на стадии закупок, так и на стадии снабжения. Предприятия нуждаются в сочетании: долгосрочных и краткосрочных планов маркетинговых мероприятий; расширение спектра методов исследования рынка и мер маркетинговой деятельности; учет результатов маркетинговой деятельности в процессе усовершенствования бизнес-моделей развития предприятий. Также в статье определены особенности современного этапа развития маркетинга, под влиянием которых происходит практически изменение модели маркетинговой системы. На основе обобщения действия фракторов развития маркетинга, а также основных тенденций авторами идентифицированы основные модели маркетинга, среди которых цифровой, ситуативный и индивидуально ориентированный маркетинг.

Ключевые слова: маркетинг, маркетинговая деятельность, составляющие маркетинговой деятельности, управление маркетингом, цифровой маркетинг, ситуативный маркетинг, индивидуально-ориентированный маркетинг.

The article examines the theoretical aspects of managing the marketing activities of the enterprise in modern business conditions and under the influence of the COVID-19 pandemic. Based on the study of "marketing management" concept, key approaches and emphases to its provision were identified. The article investigates the model of management of marketing activities of the enterprise, taking into account the needs of the modern market and the goals of achieving the effectiveness of marketing and activities of the enterprise as a whole. Marketing is considered an important component of the enterprise, and therefore in the management process, it is important to understand the functional tasks of the subsystem of marketing management, the principles of marketing management. The key factor influencing marketing concepts and business development models in general is the COVID-19 pandemic. The marketing management process should consider the dynamic change in consumer behavior. The article identifies key trends in the development of the concept of marketing under the influence of the pandemic, among which the authors noted: there was a limitation of the horizon of a long-term vision of consumer behavior and reorientation to online activities; changing the style of communication between producer and consumer; price instability in the markets of most products; change of logistics supply chains, both at the procurement stage and at the supply stage. Businesses need a combination of: Long-term and short-term plans for marketing activities; Expanding the range of market research methods and marketing activities; Taking into account the results of marketing activities in improving business models of enterprise development. The article also identifies the features of the current stage of marketing development, under the influence of which there is a change in the model of the marketing system. Based on the generalization of the factors of marketing development and the main trends, the authors identified the main marketing models, including digital, situational, and individual-oriented marketing.

Keywords: marketing, marketing activities, components of marketing activities, marketing management.

Постановка проблеми. Пандемія COVID-19 суттєво вплинула бізнес-процеси переважної більшості підприємств, в тому числі, на маркетингову діяльність, управління якою у сучасних умовах потребує не лише врахування зміни поведінки споживачів, а й застосування інноваційних технологій, зміни загальної концепції.

Аналітики McKinsey\&Company [7] визначили 8 сорер життєдіяльності людини, які зазнали найбільших змін у період пандемії: робота (перехід в он-лайн та зростання безробіття), купівля та споживання (розвиток електронної комерції, перевага перевіреним брендам та магазинам ближче до житла, зменшення частоти покупок), навчання (дистанційне навчання, витрати на вивчення суміжних галузей), життя вдома (житло як місце роботи), комунікації та інфрормація (розширення методів комунікації та обсягу використовуваної інфрормації), сорера розваг (перевага цисрровим розвагам), охорона здоров'я (посилена увага до гігієни та здоров'я), подорожі та мобільність (зменшення обсягів та напрямів).

За таких умов конкуренція між виробниками зростає та набуває нових характеристик, які повинні враховуватись в процесі здійснення маркетингової діяльності. Можливість швидкого поширення та забезпечення доступу споживачів до інформації про продукцію, зміни технологій виробництва, споживчі характеристики - набувають особливого значення для підприємств та зумовлюють зміну фрорм та методів управління маркетинговою діяльністю підприємства, які потребують подальших досліджень.

Аналіз останніх досліджень та публікацій. Теоретичні аспекти управління маркетинговою діяльністю та основні принципи ведення маркетингу було досліджено багатьма українськими вченими. Серед них Балабанова Л., Петруня Ю.[8], Дашевська Т. [4], Старостіна А. [11], Соколова І., Азарян О. [10] та Райко Д. 
[9]. У їхніх працях досліджено та проаналізовано сутність управління маркетинговою діяльністю на підприємствах, а також теоретичні засади формування маркетингового менеджменту на підприємстві.

Проблемні питання маркетингової діяльності підприємства, чинники впливу на процес маркетингу та механізми його здійснення вивчалися такими зарубіжними вченими, як I. Ансоорф, Е. Дихтль, Р. Картер, Р. Коллінз, Ф. Котлер, Дж. Боуен, Дж. Мейкенз [5], С. Бунлуа, П. Джундра [12] та іншу.

Пандемія посилила використання цисррових інструментів у житті та бізнесі, щоб залишатися на зв'язку у світі, який фрізично відключений. Поширене використання цисррових інструментів стирає межі між роботою, способом життя та соціальною взаємодією, а також між такими сорерами, як мобільність, здоров'я, фрінанси та маркетинг. Питання цифррового маркетингу, як сучасного тренду розвитку маркетингу, певним чином знайшли своє відображення в наукових працях, зокрема, слід вказати роботи Бабко Н.М., Квятко Т.М. та інш. [2], Даша Г. та Чакроборті Д. [14], Кемела А. [17], інших.

Маркетингова діяльність, як й інші ссрери діяльності підприємства, зазнають змін та потребують застосування управлінських інструментів з урахуванням умов в розрізі практики та трансформації концептуальних положень, які потребують активних досліджень у сучасних умовах.

Метою статті $є$ дослідження особливостей здійснення маркетингової діяльності, зумовлених дією пандемії та визначення інноваційних методів управління нею за сучасних умов.

Виклад основного матеріалу дослідження. Маркетинг ґрунтується на концепції та переконаннях, згідно з якими маркетологи намагаються визначити та відповісти на вимоги та бажання цільових ринків краще, ніж конкуренти [19]. Американська асоціація маркетингу трактує маркетинг як прогнозування, управління економікою та попитом на товари чи послуги з метою організації людей і території у фоормі обміну [13].

Підходи до визначення поняття «управління маркетинговою діяльністю»

\begin{tabular}{|c|c|c|}
\hline Автор & Визначення & $\begin{array}{c}\text { Ключова } \\
\text { характеристика }\end{array}$ \\
\hline $\begin{array}{l}\text { А. Старостіна } \\
\text { [11] }\end{array}$ & $\begin{array}{l}\text { Під «управлінням маркетинговою діяльністю» } \\
\text { розуміє певний процес управління підприємством, } \\
\text { який ціленаправлений на визначення потреб та } \\
\text { вимог ринку з метою подальшого фрормування } \\
\text { стратегії виробництва та конкурентного розвитку } \\
\text { підприємства. }\end{array}$ & $\begin{array}{l}\text { Визначення потреб } \\
\text { та вимог ринку }\end{array}$ \\
\hline $\begin{array}{l}\text { Ф. Котлер } \\
{[5]}\end{array}$ & $\begin{array}{l}\text { Управління маркетинговою діяльністю є } \\
\text { управлінням попитом, механізм якого складається } \\
\text { з певних коштів, інструментів та зв'язків, до яких } \\
\text { і належать складові маркетинг-міксу: продукт, } \\
\text { ціна, місце поширення та просування. До того } \\
\text { ж, як показує практика, використання комплексу } \\
\text { маркетингових заходів ефективно не тільки для } \\
\text { використання можливостей, але й вимог ринку. } \\
\text { В управлінні попитом все залежить від продукт- } \\
\text { менеджера, який використовує можливості } \\
\text { цільового ринку для реалізації продукту. }\end{array}$ & $\begin{array}{l}\text { Управління попитом } \\
\text { споживачів }\end{array}$ \\
\hline $\begin{array}{l}\text { Д. Траут, } \\
\text { Е. Райс } \\
{[16]}\end{array}$ & $\begin{array}{l}\text { Маркетинг це війна конкурентів і основна ціль } \\
\text { будь-якого підприємства - перемога у ній. }\end{array}$ & $\begin{array}{l}\text { Інструмент ведення } \\
\text { конкурентної боротьби }\end{array}$ \\
\hline $\begin{array}{l}\text { В. Руделіус, } \\
\text { О. Азарян та } \\
\text { О. Виноградов } \\
\text { [10] }\end{array}$ & $\begin{array}{l}\text { Управління маркетингом є процесом, який } \\
\text { передбачає фрормування та реалізацію ідей, } \\
\text { концепцій щодо створення товару, його } \\
\text { ціноутворення, збуту, просування шляхом } \\
\text { взаємодії суб'єктів у процесі обміну. } \\
\end{array}$ & $\begin{array}{l}\text { Управління процесом } \\
\text { створення та реалізації } \\
\text { товару. }\end{array}$ \\
\hline $\begin{array}{c}\text { В. Вонг } \\
\text { та Дж. Сондерс } \\
{[16]}\end{array}$ & $\begin{array}{l}\text { Управління маркетинговою діяльністю це } \\
\text { своєрідне дослідження маркетингового } \\
\text { потенціалу підприємства, вибір цільового ринку та } \\
\text { формування дієвих інструментів для регулювання } \\
\text { маркетингової діяльності. }\end{array}$ & $\begin{array}{l}\text { Управління формуван- } \\
\text { ням інструментів здій- } \\
\text { снення маркетингової } \\
\text { діяльності. }\end{array}$ \\
\hline
\end{tabular}


Відповідно в процесі управління маркетинговою діяльністю основними акцентами дослідження $€$ врахування вимог та потреб ринку, а також діяльності конкурентів у цьому напряму.

Сутність управління маркетингом полягає в тому, щоб знайти оптимальну кількість клієнтів, необхідних для реалізації всього виробленого фрірмою в цей момент обсягу продукції [8]. Завдання управління маркетингом полягає «у впливі на рівень, час і характер попиту таким чином, щоб це допомагало організації в досягненні її цілей» [3, с. 13].

У таблиці 1 наведено зміст поняття «управління маркетинговою діяльністю», які пропонують різні науковці.

Таким чином, ключові аспекти процесу управління маркетинговою діяльністю стосуються не лише дослідження попиту, а й його формування, що дозволить забезпечити переваги над конкурентами, отримання яких вимагає активізації інноваційної діяльності. Таке комплексне бачення змісту поняття «управління маркетинговою діяльністю» дозволяє окреслити ключові сорери діяльності підприємства, які потребують удосконалення в процесі зміни концепції маркетингової діяльності. Маркетингова діяльність, серед іншого, дає можливість підприємству формувати реальні прогнозні тенденції зміни попиту споживачів, визначати очікувані характеристики продукції, що загалом сприятиме збільшенню обсягів виробництва та збуту продукції, а також забезпечувати бажаний рівень конкурентоспроможності підприємства на ринку.

Ключовим завдання діяльності будь-якого підприємства $€$ досягнення максимальноможливої ефективності та отримання прибутку. Певну роль у цих процесах забезпечує і маркетингова діяльність, для якої питання ефективності мають неабияке значення.

Формування ефективної системи управління маркетингом на практиці базується на обраній моделі здійснення маркетингової діяльності. В якості базисної моделі можна використовувати модель, яку зображено на рис. 1.

Представлена модель базується на:

поєднанні базисних фрункцій управління, зокрема, планування, організації, контролю,

врахуванні зовнішніх та внутрішніх чинників, що впливають на маркетингову політику підприємства;

виокремленні підсистеми методів управління маркетинговою діяльністю.

Основою фрормування підсистеми управління маркетинговою діяльністю мають бути такі складові як: комплексне дослідження ринку, визначення потреб споживачів, дослідження товару, ціноутворення, збут продукції, реклама.

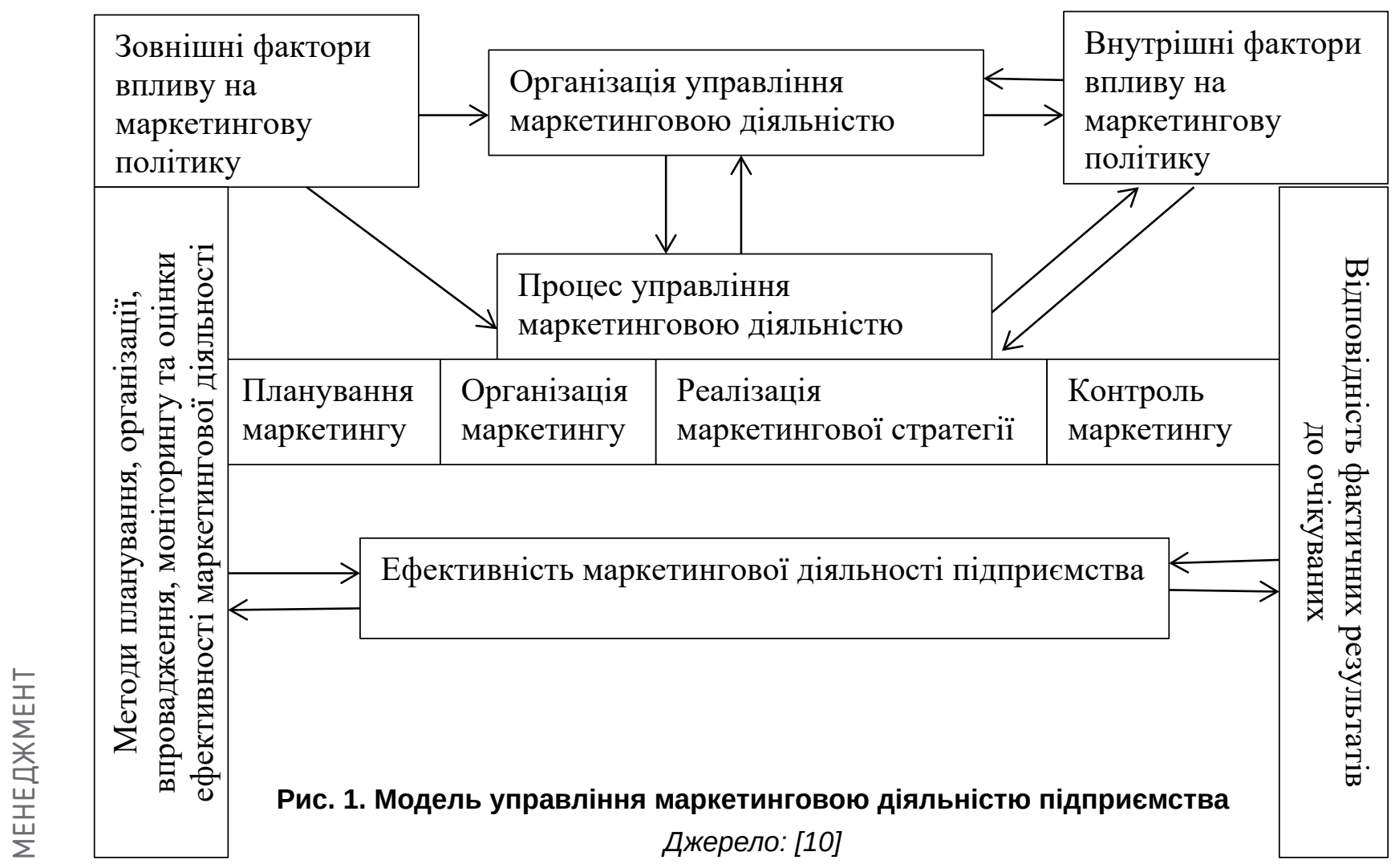


Управління маркетингом забезпечує виконання таких завдань перед підприємством [16]:

1) цільову орієнтацію ринкової діяльності;

2) комплексність зазначеної діяльності, яка виражається у технологічному процесі від розробки товару до його споживання;

3) дозволяє враховувати перспективу у вдосконаленні товарного асортименту відповідно до потреб та умов споживання.

Управління маркетинговою діяльністю на підприємстві здійснюється за такими напрямками, як організації маркетингової діяльності (служби маркетингу) та розробка і здійснення програми маркетингу.

Загалом, управління маркетингової діяльністю підприємства ґрунтується на таких принципах [6]:

чіткого розмежування зусиль підрозділів 3 різних маркетингових фрункцій: вивчення ринку, розробка нових продуктів та виробниче планування, постачання та збуту, реклами та стимулювання збуту;

усунення дублювання робіт;

комплексності ринкових досліджень, розроблення стратегічних прогнозів, оцінки едективності стратегій маркетингу.

Зазначені теоретичні положення управління маркетинговою діяльністю мають використовуються і в умовах кризових процесів, зумовлених пандемією, однак слід враховувати ті виклики, які $є$ специфрічними у сучасних умовах, та зумовлюють трансфрормацію ключових моментів.

На сьогоднішній день, в умовах пандемії COVID-19 відзначається істотний вплив на срункціонування підприємств та економіку загалом. Підприємства, які до пандемії вважалися успішними, сьогодні перебувають на межі банкрутства, а оголошені у світі карантинні заходи серйозно вдарили по бізнесу в середовищі офрлайн. За таких умов значна кількість підприємств змушені удосконалювати принципи управління маркетинговою діяльністю та залучати більш новітні форми ведення маркетингу на підприємстві.

Так, Бабко Н.М., Квятко Т.М. та інш. [2] зазначили, що основними проявами кризи стали: скорочення маркетингових бюджетів переважної більшості підприємств, переведення діяльності в режим он-лайн та скорочення працівників, зміна часового горизонту прийняття управлінських рішень у ссрері маркетингу.

Загалом слід визначити такі тенденції розвитку ринків періоду пандемії, які мали вплив на маркетингову діяльність і які стали основою системи управління.
1. Пандемія суттєво обмежила горизонт довгострокового бачення поведінки споживачів та переорієнтувала на зусилля маркетологів на он-лайн заходи. Стратегічний підхід, взятий за основу управління діяльністю сучасних корпорацій, передбачає серед іншого розробку й маркетингових стратегій. Зміни, які відбулись у потребах споживачів, імовірно залишаться після пандемії та будуть впливати на майбутні тенденції галузі.

2. Переважаючий стиль спілкування між виробником та споживачем до пандемії вічна-віч замінено на онлайн-обмін. Обмеження пересування та мобільності через карантинні заходи актуалізували розвиток цифрового маркетингу та опанування фрірмами його інструментарієм.

3. Динамічна зміна попиту та пропозиції призвела до нестабільності цін на ринках більшості найменувань продукції виробників, а отже потребує перегляду структури витрат, в тому числі на маркетингові заходи.

4. Зміна логістичних ланцюгів постачання, як на стадії закупівель, так і на стадії постачання, що більшою мірою бути призводити до орієнтації виробництва на клієнтів. Одним із головних трендів сучасності стає безконтактна кур'єрська доставка, що визначає розвиток доставки за допомогою «дронів» та «автопілотної» доставки.

У роботі [6] здійснено групування компаній за ознакою адаптації маркетингової діяльності до умов пандемії. Компанії в умова пандемії:

по-перше, повністю припинили маркетингові заходи та перебували у стагнації під час карантину;

по-друге, переклали маркетинговий бюджет, що вивільнився, для реалізації стратегії інтернет-маркетингу та підтримували інтерес споживачів у час карантинних заходів, щоб після зняття обмежень швидко повернути покупців у офрлайн точки;

по-третє, закрили офлайн-точки та перевели бізнес в онлайн.

Як показує практика, скорочення маркетингової діяльності та бюджету в період пандемії згубно впливає на перспективи розвитку, оскільки споживачі дуже швидко переходять до конкурентів, які змогли використати кризу у своїх інтересах та залучили нових споживачів.

Відповідно до зазначених тенденцій розвитку більшості ринків можна виокремити такі особливості маркетингу на даному етапі:

постійний моніторинг зміни потреб споживачів та забезпечення швидкої реакції на запити споживачів; 
перегляд методів ведення конкурентної боротьби та застосування основних маркетингових інструментів;

удосконалення структури витрат за напрямами маркетингової діяльності;

розширення спектру інноваційних інструментів маркетингової діяльності.

Під впливом зазначених процесів фрактично відбувається зміна моделей маркетингової системи: 3 класичної моделі «4Р» до розширеної моделі «7Р». Чотири елементи (продукт, ціна, розподіл, споживання) мають змогу бути цілком підконтрольними підприємством, проте започаткована концепція «7Р» встановила більш розширені взаємозв'язки системи маркетингу (продукт, ціна, розподіл, споживання, персонал, процеси, фрізичне оточення), які в умовах пандемії розширюють масштаби маркетингової діяльності. Подальшим напрямом розвитку моделей ведення маркетингової діяльності

$€$ розширення моделей «4Р» та «7Р» шляхом розширення їх елементів до «8Р» для компаній, що ведуть онлайн-діяльність шляхом включення партнерів (partners).

Відповідно відбувається пошук нових підходів до управління маркетинговою діяльність у розрізі концептуальних підходів та реальних практичних інструментів.

Узагальнюючи основні тренди у розвитку концепції маркетингу, які пришвидшились в умовах пандемії слід вказати розвиток цифрового, ситуативного та індивідуально-орієнтованого маркетингу (табл. 2).

Цифровий маркетинг - це процес просування товарів та адміністрування 3 викорис- танням комп'ютеризованих каналів транспортування через ПК, мобільні телефони, КПК або інші автоматизовані гаджети [12].

Циоровий маркетинг зробив революцію в тому, як компанії керують і взаємодіють зі своїми споживачами та суспільством у глобальному масштабі. Він стає важливим і необхідним інструментом для вирішення проблем у сорері маркетингу.

Результатом розвитку цифррових технологій та цифрового маркетингу $є$ динамічний розвиток електронної комерції - способу здійснення торговельних та фрінансових операцій, а в окремих випадках і бізнес-процесів, 3 використання комп'ютерних мереж.

Ситуативний маркетинг - процес акцентування уваги споживачів на безпечності для здоров'я діяльності та продукції компанії за рахунок додаткових заходів, що має найбільше значення в умовах пандемії. Ситуативний маркетинг на практиці означає прийняття рішення у сорері маркетингу відповідно до ситуацій, які, в окремих випадках, швидко змінюють.

Індивідуально-орієнтований маркетинг процес врахування мінливої поведінки споживачів, яка має бути врахована в процесі розробки бізнес-стратегій. Компанії повинні розуміти споживчу реакцію на пандемію. Особливістю процесу управління маркетингом в таких умовах є пошук та підбір нових концепцій для збереження та розширення клієнтського попиту. Випередження конкурентів для отримання лідерських позицій вимагає від підприємств поєднання як традиційних, так й інноваційних інструментів, укріплення бренду та активізації інноваційної діяльності. Актуальна

Таблиця 2

Характеристики сучасних моделей маркетингу

\begin{tabular}{|c|c|c|}
\hline Цифровиий маркетинг & Ситуативний маркетинг & $\begin{array}{c}\text { Індивідуально- } \\
\text { орієнтований маркетинг }\end{array}$ \\
\hline $\begin{array}{l}\text { - орормування комплексу } \\
\text { інорормації про споживачів } \\
\text { та їх вподобання; } \\
\text { - здійснення комунікацій } \\
\text { через інтернет; } \\
\text { - зміна каналів продажу } \\
\text { продукції; } \\
\text { - накопичення інформмації } \\
\text { щодо клієнтів через } \\
\text { створення маркетингових } \\
\text { платорорм; } \\
\text { - застосування широкого } \\
\text { спектру цифррових } \\
\text { інструментів просування } \\
\text { інсрормації. }\end{array}$ & $\begin{array}{l}\text { - використання певних } \\
\text { подій для проведення } \\
\text { маркетингових заходів; } \\
\text { - оперативне врахування } \\
\text { запитів споживачів; } \\
\text { - формування лояльності } \\
\text { клієнтів з рахунок розуміння } \\
\text { аудиторії та укріплення } \\
\text { позицій на ринку; } \\
\text { - динамічна зміна фрорм } \\
\text { та методів маркетингової } \\
\text { діяльності з орієнтацією } \\
\text { на зміну запитів. }\end{array}$ & $\begin{array}{l}\text { - активна взаємодія } \\
\text { зі споживачем на етапі } \\
\text { визначення потреб; } \\
\text { - реалізація споживачу } \\
\text { набору продукції; } \\
\text { - максимізація угод } \\
\text { з наявними споживачами; } \\
\text { - співробітнцтво } \\
\text { зі споживачами щодо } \\
\text { визначення перспективного } \\
\text { попиту; } \\
\text { - пошук цифрових } \\
\text { інструментів скорочення } \\
\text { відстані між споживачем } \\
\text { та виробником. }\end{array}$ \\
\hline
\end{tabular}

Джерело: складено авторами 
та грамотна політика просування бренду компанії під час кризи забезпечить стабільність позицій та іміджу в очах споживача, а також допоможе перевершити конкурентів.

Висновки. Нові ринкові умови діяльності, зумовлені пандемією, вимагають адаптації всього комплексу маркетингових заходів та підвищує їх значимість у розвитку підприємств в цілому. Пандемія миттєво змінила набір успішних маркетингових технологій та поставила загалом результати діяльності бізнесу від його спроможності адаптувати ринкові та маркетингові інструменти до цих змін.

Підприємства потребують поєднання:

довгострокових та короткострових планів маркетингових заходів; розширення спектру методів дослідження ринка та заходів маркетингової діяльності;

врахування результатів маркетингової діяльності в процесі удосконалення бізнесмоделей розвитку підприємств.

Для укріплення позицій підприємства на ринку зростає значення пошуку нових видів продукції, а отже інноваційної діяльності.

Ключовими фрормами маркетингової діяльності, розвиток яких прискорився в умовах пандемії стали цифровий маркетинг, ситуативний маркетинг та індивідуальноорієнтований маркетинг. Комплексний підхід до реалізації маркетингу означає врахування як поточних, так довгострокових запитів споживачів.

\section{СПИСОК ВИКОРИСТАНИХ ДЖЕРЕЛ:}

1. Абрамович І.А., Воловик Д.В. Маркетингова діяльність підприємства та контроль за їі реалізацією. Агросвіт. 2020. № 10. С. 52-57.

2. Бабко Н.М., Квятко Т.М., Дузькрятченко В.В., Микитась А.В. Особливості маркетингової діяльності компанії в умовах пандемії коронавірусу. Університетські наукові записки. 2020. № 3-4(75-76). С. 86-92.

3. Данько Т.П. Управление маркетингом : учебник. Изд. 2-е, перераб. и доп. Москва : ИНФРА-М, 2001. 334 с.

4. Дашевська Т.Ш., Павленко І.І. Поняття та суть маркетингу в діяльності підприємств. Вісник УНУ. Економічні науки. 2015. № 3. С. 92-94.

5. Котлер Ф., Боуэн Дж., Мейкенз Дж. Маркетинг. Гостеприимство. Туризм : учебник. Москва : Юнити-Дана, 2012. 1071 c. URL: https:// tourlib.net/books_tourism/kotler_tourism_01.htm

6. Маказан Є.В. Сучасні маркетингові принципи управління підприємством. Вісник Приазовського державного технічного університету. 2019. Вип. 31. Т. 2. С. 49-54.

7. Палка І.М. Вдосконалення системи управління маркетинговою діяльністю на підприємстві. Ефективна економіка. 2015. № 11. URL: http://www.economy.nayka.com.ua/?op=1\&z=4498

8. Петруня Ю.Є., Петруня В.Ю. Маркетинг. Дніпропетровськ : Університет митної справи та фінансів, 2016. 362 с.

9. Райко Д.В. Модель управління маркетингом у системі менеджменту промислового підприємства. Маркетинг і менеджмент інновацій. 2015. № 1. С. 107-123.

10. Руделіус В., Азарян О.М., Виноградов О.А. Маркетинг : підручник. Київ : Навчально-методичний центр "Консорціум із удосконалення менеджмент освіти в Україні", 2009. 231 с.

11. Старостіна А.О., Черваньов Д.М., Зозульов О.В.. Маркетинг : навчальний посібник. Київ : Знання-Прес, 2002. $191 \mathrm{c}$.

12. Chaffey D. Digital Marketing; Pearson: London, UK, 2019.

13. Churwiruch N., Jhundra-Indra P., \& Boonlua S. Marketing Innovation Strategy and Marketing performance: a conceptual framework. Allied Academies International Conference. Academy of Marketing Studies. 2015. 20(2): 82-93.

14. Dash G., Chakraborty D. Digital Transformation of Marketing Strategies during a Pandemic: Evidence from an Emerging Economy during COVID-19. Sustainability. 2021. 13(12): 6735. DOI: https://doi.org/10.3390/su13126735

15. Diez-Martin F., Blanco-Gonzalez A., Prado-Roman C. Research Challenges in Digital Marketing: Sustainability. Sustainability. 2019. 11: 2839.

16. Hurbyk Yu.Yu., Kychak Yu.S. (2020) Traktuvannia poniattia «marketynh»: poliaspektnyi pidkhid [Interpretation of the concept of «marketing»: a multifaceted approach]. The 8th International scientific and practical conference «Modern science: problems and innovations» (October 18-20, 2020) Stockholm, SSPG Publish, pp. 389-392.

17. Kamel A.E. The impact of COVID-19 pandemic on marketing philosophy. Delta University Scientific Journal. April 2021. Volume 4. Issue 1.

18. Kohli S., Timelin B., Fabius V., Moulvad Veranen S. How COVID-19 is changing consumer behavior now and forever. McKinsey\&Company. URL: http://surl.li/apqsi

19. Kotler P., Armstrong G., Harris L. C., \& He H. Principles of Marketing (European Edition). London : Prentice Hall, 2019. 


\section{REFERENCES:}

1. Abramovich I.A., \& Volovik D.V. (2020) Marketynhova diyal'nist' pidpryyemstva ta kontrol za yiyi realizatsiyeyu [Marketing activities of the enterprise and control over its implementation]. Agrosvit, 10(1), 52-57.

2. Babko N.M., Kvyatko T.M., Duzkryatchenko V.V., \& Mikitas A.V. (2020) Osoblyvosti marketynhovoyi diyal'nosti kompaniyi v umovakh pandemiyi koronavirusu [Features of the company's marketing activities in the context of the coronavirus pandemic]. University Scientific Notes, 3-4 (75-76), 86-92.

3. Danko T.P. (2001) Upravleniye marketingom: Uchebnik. [Marketing Management: A Textbook]. Moscow: INFRA-M, 334.

4. Dashevskaya T.Sh., Pavlenko I.I. (2015) Ponyattya ta sut marketynhu v diyalnosti pidpryyemstv [The concept and essence of marketing in the activities of enterprises]. Bulletin of the UNU. Economic Sciences, 3(1), 92-94.

5. Kotler F., Bowen J., Mackenzie J. (2012) Marketing. Gostepriimstvo. Turizm : uchebnik [Marketing. Hospitality. Tourism: a textbook]. Moscow: Unity-Dana, 1071. Available at: https://tourlib.net/books_tourism/kotler_tourism_01.htm

6. Makazan E.V. (2019) Suchasni marketynhovi pryntsypy upravlinnya pidpryyemstvom [Modern marketing principles of enterprise management]. Bulletin of the Azov State Technical University, 31(2), 49-54.

7. Stick I.M. (2015) Vdoskonalennya systemy upravlinnya marketynhovoyu diyal'nistyu na pidpryyemstvi [Improving the management system of marketing activities at the enterprise]. Efektyvna ekonomika, 11(1). Available at: http://www.economy.nayka.com.ua/?op=1\&z=4498

8. Petrunya Y.E., \& Petrunya V.Y. (2016) Marketynh [Marketing]. Dnipropetrovsk: University of Customs and Finance, 362.

9. Raiko D.V. (2015) Model' upravlinnya marketynhom u systemi menedzhmentu promyslovoho pidpryyemstva [Marketing management model in the management system of an industrial enterprise]. Marketynh i menedzhment innovatsiy, 1(1), 107-123.

10. Rudelius V., Azaryan O.M., \& Vinogradov O.A. (2009) Marketynh: pidruchnyk [Marketing: textbook]. Kyiv: "Konsortsium iz udoskonalennya menedzhmentosvity v Ukrayini, 231.

11. Starostina A.O., Chervanyov D.M., \& Zozulov O. V. (2002) Marketynh: navchal'nyy posibnyk [Marketing: a textbook]. Kyiv: Knowledge Press, 191.

12. Chaffey D. (2019) Digital Marketing; Pearson: London, UK.

13.Churwiruch N., Jhundra-Indra P., \& Boonlua S. (2015) Marketing Innovation Strategy and Marketing performance: a conceptual framework. Allied Academies International Conference. Academy of Marketing Studies, 20(2), 82-93.

14. Dash G., \& Chakraborty D. (2021) Digital Transformation of Marketing Strategies during a Pandemic: Evidence from an Emerging Economy during COVID-19. Sustainability, 13(12), 6735. DOI: https://doi.org/10.3390/ su13126735

15. Diez-Martin F., Blanco-Gonzalez A., Prado-Roman C. (2019) Research Challenges in Digital Marketing: Sustainability. Sustainability, 11(1), 2839.

16. Hurbyk Yu.Yu., Kychak \& Yu.S. (2020) Traktuvannia poniattia «marketynh»: poliaspektnyi pidkhid [Interpretation of the concept of «marketing»: a multifaceted approach]. The 8th International scientific and practical conference «Modern science: problems and innovations» (October 18-20, 2020) Stockholm, SSPG Publish, 389-392.

17. Kamel A.E. (April 2021) The impact of COVID-19 pandemic on marketing philosophy. Delta University Scientific Journal, vol. 4, iss. 1.

18. Kohli S., Timelin B., Fabius V., \& Moulvad Veranen S. How COVID-19 is changing consumer behavior now and forever. McKinsey\&Company. Available at: http://surl.li/apqsi

19. Kotler P., Armstrong G., Harris L. C., \& He H. (2019) Principles of Marketing (European Edition). London: Prentice Hall. 